September 2009

\title{
The Release, Transfer and/or Use of Imprisoned Criminals and/or Known Gangsters During the Commission of Acts Potentially Leading Up to Genocide: A Clear and Unmistakable Early Warning Signal of a Failed State - Some Preliminary Thoughts
}

Samuel Totten

University of Arkansas, Fayetteville, stotten@uark.edu

Follow this and additional works at: https://digitalcommons.usf.edu/jacaps

\section{Recommended Citation}

Totten, Samuel (2009) "The Release, Transfer and/or Use of Imprisoned Criminals and/or Known Gangsters During the Commission of Acts Potentially Leading Up to Genocide: A Clear and Unmistakable Early Warning Signal of a Failed State - Some Preliminary Thoughts," Journal of African Conflicts and Peace Studies: Vol. 1: Iss. 2, 43-67. DOI: http://dx.doi.org/10.5038/2325-484X.1.2.3

Available at: https://digitalcommons.usf.edu/jacaps/vol1/iss2/5

This Article is brought to you for free and open access by the Open Access Journals at Digital Commons @ University of South Florida. It has been accepted for inclusion in Journal of African Conflicts and Peace Studies by an authorized editor of Digital Commons @ University of South Florida. For more information, please contact digitalcommons@usf.edu. 


\author{
Journal of African Conflicts and Peace Studies
}

\begin{abstract}
THE RELEASE, TRANSFER AND/OR USE OF IMPRISONED CRIMINALS AND/OR KNOWN GANGSTERS DURING THE COMMISSION OF ACTS POTENTIALLY LEADING UP TO GENOCIDE: A CLEAR AND UNMISTAKABLE EARLY WARNING SIGNAL OF A FAILED STATE -. SOME PRELIMINARY THOUGHTS
\end{abstract}

\title{
Samuel TOTTEN
}

Introduction

Time and again throughout the $20^{\text {th }}$ century -- and now the early $21^{\text {st }}$ century -perpetrators of genocide have made use of both imprisoned criminals and/or known gangsters to assist with the perpetration of genocide. More specifically, in all of the following cases, perpetrators released imprisoned criminals and/or enticed gangsters to take part in the genocidal process: the Ottoman Turk genocide of the Armenians (1915-1919); the Nazi-perpetrated Holocaust (1933-1945); the genocide of communists and suspected communists in Indonesia in the mid-1960s; the mass murder and genocide perpetrated in the former Yugoslavia (1990s); the Hutu-genocide of Tutsis and moderate Hutus in Rwanda (1994); and the current genocide in Darfur (2003-present). Among the various criminal activities that such individuals engaged in during various periods of genocide are as follows: to terrorize innocent citizens; physically attack the victims' homes or business; help with rounding up the victims and/or deporting members of the targeted groups; over-seeing and brutalizing members of the victim group being held in detention centers, concentration camps, and/or death camps; and/or taking part in the actual killing process.

Any government that releases hardened criminals from prison and/or recruits gangsters from society, either individually or en masse, to commit crimes is plainly in the wrong. Concomitantly, when criminals are either freed en masse from prison and/or recruited from the streets and used for the express purpose to harass, intimidate, threaten and kill perceived enemies of the government, it is a clear and unequivocal warning sign that egregious acts such as crimes against humanity and/or genocide are likely to be perpetrated. 


\title{
Journal of African Conflicts and Peace Studies
}

\section{The Use of Criminal Elements for Genocidal Purposes}

\begin{abstract}
Any society anywhere would look askance at a government freeing hardened, violent criminal en masse from prison prior to the completion of their sentences. Such a release would likely result in mass fear that criminal activity would rise and that the safety of the community and its members would be at risk. That is particularly true if the individuals released were convicted murderers and rapists. Indeed, such an event in a "normal" society would likely result in a massive outcry of concern, if not severe repercussions for the individual(s) who ordered the release. Indeed, those responsible for such an egregious act would likely be terminated immediately from their positions and prosecuted to the full extent of the law.
\end{abstract}

More graphically stated, one can imagine how, for example, citizens in the U.S. would react if the following convicts (or similar ilk) were cavalierly released into society: Charles Manson (a convicted serial killer who founded a hippie cult known as "The Family" and ordered the vicious bludgeoning of pregnant actress Sharon Tate and her friends); Ted Kaczynski (the so-called Unabomber); John Wayne Gacy (the worst serial killer at the time of his conviction for the murders of 33 young boys and men who he lured to his home with the promise of a job in construction and then sexually assaulted, tortured and strangled them with a rope); Richard Speck (a mass murderer who killed eight student nurses from South Chicago Community Hospital in Chicago); or Timothy McVey (who, on April 19, 1995, blew up a federal building in in Oklahoma City, killing 168 innocent people, in the bloodiest terrorist attack to that point in time on U.S. soil). The release of such individuals into society for no apparent reason (or worse, to work for the government in some capacity) would be perceived as an outrage, pure and simple. Indeed, it would make headlines in newspapers across the nation and globe, as well as be the focus of radio, television and internet news coverage.

When individuals who have been convicted of heinous crimes and are serving prison sentences are released in any society anywhere across the globe, it should be cause for alarm -- not only within the society itself but by the international community. With few exceptions (e.g., the eruption of sudden mayhem in a society or a major terrorist attack), there is little else that is likely to be as startling or disturbing as the major release of violent criminals into a society. At the least, it is a sign of a dysfunctional, if 


\section{Journal of African Conflicts and Peace Studies}

not a failed, society -- a society that is likely to be on the verge of literally hemorrhaging its lifeblood.

When such releases are made the international community need not - and should not - wait for any other signs that something ominous, dangerous or deadly is about to happen. Again, that is due to the simple but profound fact that no word, few directives, and hardly any actions are as blatantly suggestive that something catastrophic is on the horizon.

While individual scholars writing about a specific genocide have commented on the use of convicted, violent criminals by perpetrators to carry out genocidal acts, those engaged in comparative genocide studies have overlooked the fact that "common" criminals have had a role time and again in many genocides perpetrated throughout the twentieth century.

\section{An Early Warning Signal or An Actual Signal Genocide is Under Way}

A wide range of words and actions can and should serve as "genocide early warning signals." No one, except the perpetrators, ever know if their words and actions early on will actually eventuate in genocide (and in many cases, not ever they do), but the express purpose of monitoring and acting on such signals is to prevent genocide from becoming a reality. Among some of the many early warning signals scholars have delineated over the years are as follows: "sharp internal cleavages combined with a history of struggle between groups prior to the upheaval" (Harff, cited in Alvarez, 2001, p. 133); the dehumanization of the target group; an "escalating series of human rights violations" (Fein, 2000); the printing, distribution and use of "antisemitic or other prejudicial material for attracting sympathizers and recruiting members" (Littell, 1999, p. 263); the cultivation of "the politics of verbal assault and physical violence, e.g., publishing slanderous charges, bombing meeting places and homes and media, beating and assassinating opponents" (Littell, 1999, pp. 263-264); the round-up and incarceration of targeted groups; the forced deportation of targeted groups; and an ever-increasing, or sustained, series of massacres targeting a specific group.

As noted earlier, the release from prison of substantial numbers of violent criminals prior to having served their full sentences is a clear early warning signal that something is terribly wrong in the society and that something approaching mass violence is likely on the horizon. When such criminals are let out for the express 


\section{Journal of African Conflicts and Peace Studies}

purpose of assisting a regime to harass, intimidate, terrorize, injure and possibly murder a targeted group that constitutes an even clearer early warning signal.

When members of the press, nongovernmental organizations, other states, and/or the United Nations hear about or observe such an aberration taking place it is a sign that must be heeded immediately, for what it is bound to result in is no good (meaning, that serious civil and/or human rights violations are, more than likely, about to become the law of the land).

What underscores the notion that the latter situation actually constitutes a potential genocide early warning signal is the fact that the use of criminals in such a manner has, as mentioned above, taken place time and again during the course of various genocides. ${ }^{1}$ The co-conspirators of such genocides knew full well that their actions

\footnotetext{
1 Only by comparative study of various genocides will scholars and practitioners be able to develop an effective means to genocide intervention and prevention. One of the key components of the latter is ascertaining specific actions of genocidaires that seem to suggest a situation might be slouching towards genocide. Such actions can, ultimately, serve as a set of genocide early warning signals. In an essay entitled "Conducting a Comparative Study of Genocide: Rationale and Methodology," Henry Huttenbach (2004) writes as follows:
}

Comparison is the sine qua non of genocide studies. It lies at the heart of the methodological way of understand-ing genocide per se and not just on the basis of familiarity with one or perhaps two instances of genocide....[C]omparison is a necessary tool with which to... highlight common features that individual genocides share with others. [N]ot all similarities and/or differences are equally important or insightful. There are degrees of significance, from the trivial to those opening up ground-breaking new vistas (p. 240).

Huttenbach (2004) goes on to state that

...The entire first rubric - pre-genocide -- needs careful comparative investigation. To locate the beginnings or roots of genocide in the near and more distant past is a much desired skill. What prompts this is the hope that by uncovering the causality of an event one can project - by extension - or anticipate genocidal incidents in the future. If one could fix a common past to most genocides, then one might come closer to anticipating and, thereby, preventing a future genocidal crisis. The search for early warning systems is a skill many ...concerned with genocide hope to acquire. After all, a primary reason for genocide research is to see whether one or more genocides could have been avoided. Thus, hindsight, one hopes, can be translated into foresight if a pre-genocide pattern or patterns can be ascertained.

To come close to this ideal one must first of all search for clues on a comparative level. Each genocide may have had its own distinct past; yet there may also be a common denominator. Only the comparative method will yield results to this problem. If, for example, one defines genocide as a particular mode of human rights violation, then by means of careful monitoring of the violation and/or 
Totten: The Release, Transfer and/or Use of Imprisoned Criminals and/or K

\section{Journal of African Conflicts and Peace Studies}

were illegal and barbarous, but they were intent on carrying out their goal, no matter the cost. Of course, those intending to carry out a genocide hardly concern themselves with the illegality of their actions.

Far too often when a potential or actual genocide is on the horizon, the press, human rights activists, the United Nations, the governments of independent nations, and even genocide scholars, hem and haw, debate and dither while attempting to ascertain whether a violent conflict actually constitutes genocide or not. That is exactly what took place prior to and during the relatively recent genocides in the former Yugoslavia, Rwanda and Darfur.

As many scholars, activists and others have argued, repeatedly, what is most important when an atrocity breaks out is not the naming of the action (e.g., "genocide," "rolling genocide," "genocide by atrocity," "crimes against humanity," "war crimes" or "ethnic cleansing," etc.), but rather to halt the atrocities as quickly as possible. But the sad fact is, even if the international community skipped over the "naming" of the atrocity, it probably would still engage in a lot of "hoing" and humming as it attempted to ascertain just how serious the atrocity was likely to be before taking any concrete action. The point is, though, if a situation arises in which a government begins freeing violent criminals from their cells -- especially en masse and prior to having completed their sentences -- to reenter society then there is little need to debate the seriousness of the situation. Rather, it should be crystal clear that the situation is a crisis and necessitates a quick and effective response. Furthermore, it should be obvious that any government that releases such individuals can no longer be considered capable of protecting its own citizens.

\section{Genocides in Which Hard-Core Convicts Were Released from Prison or Recruited from Criminal Ranks in Society in Order to Take Part in a Genocide}

Herein, a very brief overview is presented of some of the many cases of genocide over the past two centuries where perpetrators of genocide made use of either imprisoned convicts and/or gangsters on the street to assist with various facets of the genocidal enterprise. What is of particular interest is that perpetrators of genocides of all types

support of collective human rights, observers of the present could be helped in pointing to a crisis that might mature into genocide (p. 245). 


\section{Journal of African Conflicts and Peace Studies}

carried out in various parts of the world, both in the distant past as well as quite recently, have made use of incarcerated criminals and gangsters from the street to carry out their dirty work.

\section{Armenian Genocide}

At the outset of the Armenian genocide in 1915, the Young Turk Ittihadists" "secretly formed a unit called the Special Organization, one of whose principal purposes was resolving the Armenian question. ${ }^{3}$ Equipped with special codes, funds, cadres, weapons, and ammunition, they functioned as a semi-autonomous 'state within the state"' (Dadrian, 1997, p. 236). Putting it more bluntly, Adalian (2004) asserts that the Special Organization's primary mission "consisted solely of reducing the number of the Armenians by carrying out massacres" (Adalian, 2004, p. 81). Significantly, as Dadrian (2005) notes, "the primary executioners [during the genocide] were the tens of thousands of convicts of the Special Organization...." (p. 74). Such criminals [were] "released from the Empire's prisons by a special dispensation issued by the Ministries of both Interior and Justice. In his testimony before the Fifth Committee of the Ottoman Chamber of Deputies on November 10, 1918, ex-Justice Minister Ibrahim acknowledged such a release of convicts from the prisons" (Dadrian, 1997, p. 236). Mazian (1990) writes that even criminals who had been sentenced to death were freed

\footnotetext{
2 The Young Turks perpetrated the Armenian Genocide. The Young Turk Movement, "whose foundational base was a group of young military officers disturbed by the diminution of Ottoman power and prestige, arose as a reaction to the dictatorship of Sultan Abdul-Hamid II (1876-1909). In 1895 the Young Turks established the Committee of Union and Progress (CUP) (Ittihad ve Terakki Jemiyeti) to serve as its organizational body, and as a result the Young Turks were often referred to as Ittihadists or Unionists.

${ }^{3}$ The Armenian Question was a term used "to describe the issue of how to bring about reforms in the condition of the Armenian population of the Ottoman Empire during the reign of Sultan Abdul Hamid II (reigned from 1876 to 1909). In the latter part of the nineteenth century, the Ottoman reform movement known as Tanzimt attempted to restructure society on constitutional and social liens, trying to bring the Ottoman Empire closer to modern European standards. The Armenians of the empire, encouraged by this development, hoped that an alteration to their status as second-class citizens might follow; consequently, a number of petitions were sent to the grand vizier's office in Constantinople requesting protection from Turkish violence and ill treatment in the provinces. Such requests were viewed by Abdul Hamid and his government as an affront to the sultan's authority. As the problem of how to treat the Armenians (and by extension, other non-Muslim minorities in the empire) began to attract the attention of Europe's Christians nations, the sultan's thoughts turned to the most efficient way to solve it. His decision, by 1894 , was that the only viable way to get rid of the 'Armenian Question' would be for the Armenians themselves to be eradicated" (Totten and Bartrop, 2008, p. 23).
} 
Totten: The Release, Transfer and/or Use of Imprisoned Criminals and/or K

\section{Journal of African Conflicts and Peace Studies}

from prisons throughout the Ottoman Empire in order to join the Special Organization (p. 63). ${ }^{4}$

Those who formed the Special Organization knew full well that their actions were aberrant, and, accordingly, they attempted to couch the purpose of the organization in euphemistic language that attempted to hide the criminal intent of it (Dadrian, 1997, pp. 236-237). Subsequently, the effort to enlist criminals into the ranks of the army was not undertaken on the sly by some lower level army officials but was carried out in a formal manner in which various high level governmental bodies were consulted and petitioned. ${ }^{5}$ The point is, the Ottoman Turkish government, at the highest levels, was involved in providing their imprimatur for the release of such prisoners. Tellingly, the army went ahead with its plans prior to even receiving the imprimatur of its leaders: "When, in 1916, the draft bill to enlist convicted murderers in the Special Organization was being discussed, that organization already had all but committed its mission against the Armenians" (Dadrian, 1997, p. 237).

Once the criminals were released from prison, the Ottoman authorities placed the criminals "on the organization's rolls, formed [them] into bands, trained, and sent [them] into action in the eastern vilayets.... The Ittihad's [Young Turks] bribery funds allocated large sums of money for their equipment and training" (Mazian, 1990, p. 63). Additionally, "[p]arty leaders, deputies, and provincial secretaries-general verbally transmitted instructions to the chetehs [common criminals]" (Mazian, 1990, p. 63). Ultimately, such "troops" were attached to units of the Kurdish tribes, "and other Hamidians [a cavalry composed solely of Kurds, which was formed by Sultan AbdulHamid] to persecute the Armenians in eastern Anatolia" (Mazian, 1990, p. 63).

\footnotetext{
${ }^{4}$ Dadrian (2003) notes that "As both the late dean of Turkish political scientists, Tarik Zafer Tunaya, on the one hand, and Special Organization Operative, Arif Cemal, on the other, emphasized, 'militas' were coterminous with 'brigands' ('cetes') and 'convicts,' yet they were 'the constitutive' ('yapisal') elements of the Special Organization, the main CUP instrument in the implementation of the anti-Armenian scheme" (pp. 65-66).

Dadrian (2003) further notes that "In order to be swift and merciless in this task the organizers decided to employ thousands of convicts. Accordingly the latter were serially released from the various prison of the Empire for massacre duty. The [Turkish] Military Tribunal's key indictments a dozen times makes reference to them as the main instrument of mass murder against the Armenians" (p. 92).

${ }^{5}$ For example, Dadrian (2003) writes that "The procedures relating to the release of convicts in Trabzon province attest to a very distinct feature of the organization of the Armenian Genocide. It appears that all three.members of the CUP's [Committee of Union and Progress] Central Committee faction had a hand in enlisting and deploying multitudes of felons, who are described as 'bloodthirsty' murderers ('kanli katil'), as the main instruments of the extermination campaign (p. 94).
} 


\title{
Journal of African Conflicts and Peace Studies
}

At various points, discussions about the Special Organization were held among various senators and one senator even issued a sharp rebuke, though not specifically about the way the criminals were going to be used but rather his concern that the inclusion of criminal elements in the army would pollute the latter:

In denouncing the rationale of the bill, Senator A. Riza stated that

\begin{abstract}
"murders and criminals do not belong in the army," inasmuch as the bill was framed in such a way as to convey to impression that the recruitment was for the benefit of the army. However, Colonel Behic (Erkin) of the Supply Department of the War Ministry proudly declared in the Parliament that the majority of the convicts was being recruited not for the benefit of the army but for the Teskilati Mahsusa, the organization in which "they had proven their usefulness." ence, he argued, it was impossible for these criminals to prove pernicious to the overall morality of the army soldiers. Angered by this admission, Riza retorted: "We know about the nature of that organization. We shall call it to account in the future."... This not-withstanding, the bill was declared as "lawful" by the undersecretary of the Justice Ministry who requested and secured its passage as "an emergency" bill (Dadrian, 1997, p. 237).
\end{abstract}

Other government officials also voiced their concern about the mass release of prisoners who had been convicted for having committed, but for reasons other than those expressed by the aforementioned senator. Like him, though, their concerns were not humanitarian in intent. As Dadrian (1997) notes, "it appears that some eastern governors, anxious about the risks of their complicity [that is, allowing convicted criminals to roam their districts carrying out the mandate to ravage the Armenian population], were hedging and were demanding some legal protection" (Dadrian, 1997, p. 237).

The secret duties of the Special Organization were first brought to light when the Turkish press, in November and December 1918, following the signing of the Armistice, began publishing stories about the use of violent criminals to carry out the massacres. In a particularly scathing commentary, the opposition newspaper, Sabah, printed the following open letter addressed to the Minister of Justice:

...Did you not, as a result of a decision reached at Ittihad's party headquarters, release from the central prison of Istanbul the most ferocious murders so that they could kill with axes the innocent Armenians in the vicinity of towns and villages of which they were the inhabitants? Did you not order similar releases from prisons in the provinces? Was it not the general purpose to select the most bloodthirsty murderers and enroll them in the brigand cadres [of the Special Organization]...? Furthermore, was not a physician appointed also to determine whether the selected convicts would be fit to apply a degree of savagery of 
Totten: The Release, Transfer and/or Use of Imprisoned Criminals and/or K

\section{Journal of African Conflicts and Peace Studies}

killing you required?....Did not this organizational work continue for weeks during which one could observe the prison convicts being brought to the corridors located outside of the office of the procurorgeneral, the chamber of the Criminal Court, and the Courtroom itself? (quoted in Dadrian, 1997, p. 238).

The significance of this letter is that the release and use of criminals for genocidal purposes was not a secret, and that the general public was aware of the government's actions and its use of criminal elements for the harassment, terrorization and murder of the Armenian population. It is hard to believe that representatives (diplomats) from other countries were not aware of what was happening right under their noses. What they did with such information is another question altogether.

\section{The Holocaust}

The next major use of convicted criminals during the course of a genocide was during the German-perpetrated Holocaust of nearly six million Jews (1933-1945), and the genocide of the Gypsies and the mentally and physically handicapped. In certain cases, the Nazis transferred convicted criminals to concentration camps and/or death camps in order to serve as Kapos, or supervisors of prisoners. ${ }^{6}$ In other cases, underworld figures were sometimes used to round up Jews in Nazi-occupied territory.

As for the use of convicted criminals in the death camps, Leni Yahil (1990), a historian of the Holocaust, notes that

[W] hen Auschwitz was still in the process of being set up, Höss brought with him thirty inmates from Sachsenhausen who had been imprisoned on criminal charges and turned them into Kapos....These erstwhile criminal prisoners controlled the routine administration of the camp by means of a ruthless regime. They were present twenty-four hours a day and un-abashedly exploited the authority placed in their hands. Of course, there were also exceptions to such conduct, but in general they behaved according to the rules and ethos of the underworld society, and they enjoyed the full backing of the SS because they were a convenient tool. In the course of time, the number of these petty despots grew in all the camps, reaching into the thousands - including also Jews (p. 370).

The Nazis knew that professional criminals would not have any qualms about taking advantage of their special situations nor were they likely to "demonstrate the requisite lack of pity" (Niewyk and Nicosia, 2000, p. 18). In other words, "they were usually willing tools who had the desired levels of violence and cruelty" (Niewyk and Nicosia, 2000, p. 236).

${ }^{6}$ It is important to note that not all Kapos were hardened criminals; in fact, many were political prisoners. 


\section{Journal of African Conflicts and Peace Studies}

Women who had been convicted of criminal offenses were also used by the Nazis as enforcers in concentration and death camps. For example, German women who had been arrested for prostitution were used as "foremen" in Majdanek. A Jewish survivor of the death camp noted the following about such women:

They [the prostitutes] beast us terribly. They said that every day they must kill three, four Jews. And food they did not give us.... We got heavily beaten with rubber hoses over the legs from those German women overseers, those who were also imprisoned, prisoners (Niewyk, 2009, p. 150).

Undoubtedly, when convicted criminals are used as government instruments in concentration camps it makes it extremely difficult for those outside the camp to be cognizant of such activities. Be that as it may, the creation of concentration camps is, in and of themselves, an early warning signal that something is badly awry in a society. Furthermore, when such camps are established, it is imperative that the international community not only voice strenuous and sustained concern about such, but insist on inspecting them in order to ascertain the nature of such camps. It is at that point in time that an all effort should be made to ascertain whether criminal elements are at work therein.

It is worth noting that criminals weren't simply used as Kapos by the Nazis. In France, for example, party members of the southern branch of the Parti Populaire Francasis (PPF), some of whom were "underworld characters" (Hilberg, 1992, p. 88), helped German and French police track down Jews, most of whom were ultimately deported to the death camps in Poland.

\section{Indonesian Genocide of Communists and Suspected Communists}

Between October 1965 and March 1966 between 200,000 and 500,000 people -members of the Indonesia Communist party as well as those suspected of being Communists - were murdered in a rash of massacres carried out by the Indonesia government For the most part, the killings were carried out by anti-Communist army forces and civilian thugs. During the course of these genocide massacres, the Indonesian government not only condoned but sought the assistance of vigilantes to help with the massive amount of killing. In regard to the latter, Robert Cribb (2009), an Australian scholar, notes that "[t]here is evidence, too, that many of the vigilantes were drawn from the criminal underworld. They were men of violence ['rural and urban gangster, enforcers, and the like'] in any case and were given the freedom to exercise 


\section{Journal of African Conflicts and Peace Studies}

violence on a massive scale during the killings" (p. 240). It is believed that government purposely sought the assistance of such underworld figures due to the sheer amount of killing desired by the government. Providing greater insight into the use of such figures during the genocide, Cribb (2004a) states that

[f]or centuries, unofficial men of violence have existed on the margins of politics in the Indonesian archipelago. They have acted both as independent gangsters and as temporary agents of those in power. Their style is above all one of fearsomeness, of creating a paralyzing sense of fear in their victims. They are capable of resorting to extreme violence, but the combined force of state power and public hostility generally prevents them from doing so. News of the October 1965 coup [in which Suharto overthrew Sukarno), however, created an atmosphere of impunity in which the violent capacities of these gangsters was no longer repressed. Recruited into the civilian militias which carried out the bulk of the massacres, they wrought a terrible toll on life (p. 139).

The point about impunity is important. Seemingly, the government did not care who knew what it was doing (e.g., terrorizing and murdering communists and suspected communists) or how it was going about it (using its own military forces as well as criminal elements), and this just underscores the need for the international community to act to stanch such activities as soon as they are detected. Indeed, it does not matter whether killings begin before the recruitment of the criminals or the other way around; what is of the utmost importance is a timely and strong response sustained over time.

\section{Genocide in the Former Yugoslavia}

During the course of the internecine fighting in Yugoslavia throughout the 1990s, Serbian government officials purposely recruited known criminals into the ranks of the paramilitary groups -- both to serve in leadership positions as well as regular militia members. In fact, "warlords were composed of 20 percent fanatic Serbian nationalists and 80 percent prison inmates whom [Slobodan] Milosevic had released with the promise that they could help themselves to the possessions of the victims they were instructed to kill and/or chase" (Mueler, 1999, quoted in Semelin, 2003, pp. 366-367).

Speaking of the use of criminal elements in paramilitary groups that Slobodan Milosevic (Yugoslav president and dictator), for one, oversaw, Louis Sell (2002), author of Slobodan Milosevic and the Destruction of Yugoslavia, asserts that

The war in Croatia marked the first use of the paramilitary bands that subsequently became an ugly feature of all the Yugoslav wars. Generally organized around a widely known leader or political party, 


\section{Journal of African Conflicts and Peace Studies}

their members were often drawn from the roughest elements of the Serbian criminal underworld -motivated as much by the thrill of violence and the prospect of loot as by attachment to the Serbian cause. The paramilitaries quickly earned a fearsome reputation for murder, rape, and other forms of savagery (p. 325).

Providing additional information, Cigar and Williams 2002) note the following:

Many paramilitary commanders had been prominent figures in Serbia's underworld, to which several subsequently returned. A significant proportion of the paramilitary groups' rank-and-file also had surfaced from the criminal underworld: according to a survey conducted in 1991, some twenty percent had previous police records. The activities of the paramilitary groups, in fact, served the domestic interests of Slobodan Milosevic, while enabling him to maintain the fiction that the government was not involved (p. 97).

Among the most notorious former criminal cum paramilitary leader was the prominent warlord, Zelko Raznjatovic, commonly known as "Arkan." Arkan was leader of a vicious paramilitary group known as "The Serbian Volunteer Guard," which was more widely referred to as the "Arkan Tigers." Throughout the 1970s and 1980s, Arkan had gained notoriety as a brazen bank robber, and "reportedly also as an agent of the Yugoslav secret police responsible for attacks against émigré opponents of the Yugoslav regime" (Sell, 2002, p. 326).

In Serpent in the Bosom: The Rise and Fall of Slobodan Milosevic, Lenard J. Cohen (2001) adds the following about Arkan's background and relationship with the Serbian officials:

The impact of the wars of the Yugoslav secession on Serbia, and particularly the breakdown of routine economic activity under the pressure of United Nations sanctions, contributed to the growing criminalization of society in Serbia and Montenegro during the first half of the1990s. The most representative example of this trend was the rise of...Arkan, from a minor figure in Belgrade's underworld to a high-profile actor in Serbian political life. Wanted by Interpol and a dozen European countries in connection with bank robberies during the 1970s and 1980s, Arkan emerged as a prominent figure on the Belgrade scene when, with the help of the Serbian Ministry of the Interior, he organized paramilitary units to fight for Serb interests in Croatia and Bosnia. Arhan's Serbian National Guard, popularly known as the "Tigers," became notorious for their brutal "ethnic cleansing" campaign in Croatia and Bosnia. But the Milosevic-controlled media tumed Arkan into "a hero of the Serbian nation." ...When a Croatian diplomat conducting secret negotiations with Milosevic asked about Arkan in 1993, the Serbian president only laughed and said, "I too must have someone to do certain kinds of work for me" (p. 135). 


\section{Journal of African Conflicts and Peace Studies}

Of Arkan's relationship with Milosevic, Sell (2002) notes that Arkan

...seemed to hold a special place in Milosevic's affections. In 1991, Serbia's Milosevic-controlled media gave Arkan and his forces extensive and positive coverage, even going so far as to allow recruiting ads to appear on Belgrade television....During a secret meeting with [Franjo] Tudjman adviser Sarinic on 12 November 1993, Milosevic tacitly admitted that Arkan was acting under his control (p. 326).

In his book Fires of Hatred: Ethnic Cleansing in Twentieth Century Europe, historian Norman M. Naimark (2001) notes that among Arkan's men were "amnestied convicts looking for adventure" (p. 161). Speaking of the make-up of his group of men, Arkan reportedly told an interviewer: "Let us understand each other. We are not just talking about paramilitary units. Every member must, first of all, be responsible to the Serbian people and must respect the parliament and the president of the Republic" (cited in Naimark, 2001, p. 161). In regard to the latter statement by Arkan, Naimark comments as follows: "In short, the crimes committed by his group were state initiated and statesupported" (p. 161).

As noted above, Arkan's Tigers played a significant role in the ethnic cleansing effort carried out by the Serbs: "at the beginning of the fighting in Bosnia, Arkan himself reportedly personally directed the intimidation and expulsion of Moslems and Gypsies from Bijelina and Janja. The Tigers also played a significant role in the takeover and cleansing of such towns as Zvornik, Bijelina, Bratunac, Prijedor, and Foca" (Sell, 2002, p. 327).

The use of criminal elements to carry out illegal policies and actions contributed, in part, to the destruction of Yugoslavia. In this regard, Cohen (2001) asserts that "[t]he 'heroization' of mafia activity in Serbia made a mockery of the regime's claim to be upholding the rule of law, and transformed the climate in Milosevic's soft dictatorship into a disorderly and dangerous environment where wild and arbitrary justice became increasingly routine. Gradually, as one of Belgrade's journalists has observed, 'the celebration of criminals as national war heroes, or populist primitivism,' would transform Serbia "into an isolated fortress of "patriotic-national" uniformly thinking people'" (p. 135). 


\section{Journal of African Conflicts and Peace Studies}

\section{The 1994 Rwandan Genocide}

Prior to and during the course of the 1994 Rwandan genocide, Hutu criminals of all sorts were engaged in attacking, looting and killing Tutsi victims. Alison Des Forges (1999), an analyst with Human Rights Watch, asserts that both Rwandan soldiers and national police "in addition to killing for pay...., took part in open pillage and in hidden theft, cooperating with civilian criminals and corrupting the children of the streets to assist in burglaries. They robbed each other of the booty looted from Tutsis.... When civil authorities arrested civilians who helped soldiers in crimes, the soldiers usually were able to obtain their release" (p. 570). While the aforementioned common criminals were not, at least for the most part, committing capital crimes, the "use" of such criminals for such criminal activities does indicate and constitute a general lawlessness in a society. In such a situation, if the victims of such criminal activity are primarily, or solely, from a particular group (and/or the victim population has been singled out in one or more ways for public contempt by the perpetrator group) then that, too, should be considered another potential genocide early warning signal.

In his book, Shake Hands with the Devil: The Failure of Humanity in Rwanda, Roméo Dallaire, Force Commander of the UN Assistance Mission to Rwandan in 1993-1994, discusses the make-up of the Gendarmerie controlled by the perpetrators of the genocide, and in doing so notes he following: "Tiko [Colonel Isoa Tikoka] and Major Eddy Delporte, a Belgian military police officer who was attached to us from the UN mission in Western Sahara, conducted the analysis of the Gendarmerie. ${ }^{7}$ Their survey reveals an erratically led and undisciplined body of men who ranged from true professional police officers to out-and-out criminals in uniform" (p. 70). Again, the inclusion of outright criminals in a police or para-military force is, at the least, a clear and unmistakable sign that a society is disintegrating in a significant way. Couple that with a society where a specific group of people is being ostracized, overtly discriminated against and cast out of the mainstream (or, as genocide scholar Helen Fein eloquently puts it, placed "outside the universe of obligation"), it constitutes yet another early warning sign that something is drastically askew in that particular society and that human rights violations -- be they crimes against humanity or genocide --may not be far off.

\footnotetext{
TThe gendarmerie was a "para-military force of 6,000 members, the national police force in Rwanda, controlled by the regime, based in Kigali and Ruhengeri, trained by both Belgian and French advisors, modeled on the French equivalent. Used mainly as a police force, however units were sometimes mobilized to the front to augment the army" (Dallaire, 205, p. 530).
} 
Totten: The Release, Transfer and/or Use of Imprisoned Criminals and/or K

\section{Journal of African Conflicts and Peace Studies}

During the 1994 genocide, there were also instances where prison officials freed every single inmate in their prison ostensibly due to the difficulty of obtaining enough food and water for the prisoners. As far as can be ascertained no research has been conducted into whether those Hutu who were released joined their compatriots in the killing process or whether the Tutsis who were released were killed on the spot by their fellow prisoners. In one case, in the prison located in Huye, just on the outskirts of Butare town, it is known that many, if not most, Tutsi prisoners had been slain prior to the release of most, if not all, of the prisoners from that particular prison (interview conducted by the author, 2008).

\section{The Darfur Genocide}

It is a well-known fact that the Government of Sudan (GOS) recruits men into the Janjaweed -- the Arab militia that virtually serves as an unofficial arm of the Sudanese military in Darfur - from the criminal ranks. As Flint and De Waal (2005) write, the [GOS] army "accepts - even seeks out - the criminal element that was a defining feature of the prewar Janjawiid" (pp. 103-104).

The ranking leader of the Janjaweed, Musa Hilal, has a fairly lengthy record of violent crime. Sometime between the early to mid-1990s, he killed a security guard at a bank he (Hilal) was attempting to rob in Nyala, and was sent to prison for both crimes. Then, in 1997, he was imprisoned for purportedly killing seventeen black Africans in Darfur (Wax, 2004, p. A01). He was later arrested and imprisoned for additional crimes he allegedly committed in 2002, but the GoS "chose him to help organize the militia [the Janjaweed], according to Ted Dagne, an African specialist for the Congressional Research Service" (Wax, 2004, p. A1). Reportedly, "Hilal was released from prison after personal intervention by Sudan's first vice president, Ali Uthman Muhammad Taha, Dagne said. Another man, Gen. Abdullah Safi Nur, an Air Force commander and former commissioner of Darfur who is Hilal's cousin, also intervened, he said, adding that the Sudanese government had relied on militia leaders such as Hilal in earlier conflicts, including in southern Sudan" (Wax, 2004, p. A01).

On June 14, 2004, journalist Julie Flint testified before the U.S. Senate Foreign Relations Committee about Hilal's relationship with the GoS as well as the criminal record of another major Janjaweed leader:

Rebel leaders say they have identified six Janjaweed brigades - among them the Liwa al-Jammous, or Buffalo Brigade, and the Liwa al-Nasr, or Victory Brigade. These two brigades are headed respectively 


\section{Journal of African Conflicts and Peace Studies}

by Musa Hilal of the Um Jalloul tribe and Abdul Rahim Ahmad Mohammed, known universally as Shukurtallah, of the Mahariya tribe. Musa Hilal has enjoyed close relations with many senior government officials, prime among them a governor of North Darfur state, and is a frequent visitor to Khartoum. The Masalit say that Shukurtallah served in the army in Geneina and in Juba before being sentenced to 10 years' imprisonment for killing Masalit civilians. But he was released from jail before completing his sentence, they say, and emerged as the leader of the Janjaweed in West Darfur state. Soldier to Janjaweed, via a murder conviction, in one easy step (Human Rights Watch, 2004, p. A01).

The recruitment and use of criminals in Darfur does not stop there. Following in the steps of his GoS paymasters, Hilal has purportedly entered at least one prison and had all of the Arabs released into his custody. Speaking of this action, Flint and DeWaal (2005) report the following:

Shortly after returning to North Darfur, he [Musa Hilal] visited Kutum jail, and ordered the staff to bring all prisoners before him. One of the warders remembers him saying, "Why are Arabs in prison?" and ordering that they be released. Many such men found a haven in the Janjawid, whose own behavior was defined by its unbound criminality (p. 104).

Top government officials undoubtedly were/are aware of such actions by Hilal as the government and the Janajweed have worked hand-in-hand for years (and continue to do so to this day) in carrying out attacks against black African villages and gatherings of black Africans in internally displaced persons (IDP) camps.

\section{In Contravention of the Geneva Conventions}

In the aftermath of the Holocaust and following the judgments rendered at Nuremberg, the establishment of the Geneva Conventions made it a crime if superiors knew, in advance, that a subordinate was engaging in an acts covered by the Conventions. More specifically, Article 86 of Additional Protocol I to the 1949 Geneva Conventions states that: "The fact that a breach of the Convention or of this Protocol was committed by a subordinate does not absolve his superiors from penal disciplinary responsibility as the case may be if they knew, or had information which would have enabled them to conclude in the circumstances at the time that he was committing or was going to commit such a breach and if they did not take all feasible measures within their power to prevent or repress the breach." Furthermore, under the 1998 statute of the International Criminal Court (ICC), a military leader is culpable for any crimes that he or she "knew or should have known" about. That is, a leader is liable if he or she "failed to take all necessary and responsible measures" to prevent and halt those 
Totten: The Release, Transfer and/or Use of Imprisoned Criminals and/or K

\section{Journal of African Conflicts and Peace Studies}

crimes that his or her subordinates "were committing or about to commit." They are also liable if they neglect to report such criminal acts to his/her own superiors.

In the case of using convicted criminals or members of the underworld to commit crimes on the behalf of the government, military, or police force, those individuals who solicit the assistance of criminal elements, oversee the actions of criminals for such purposes and/or are in charge of lower level personnel who make use of such criminals would all be guilty of contravening Article 86 of Additional Protocol I to the 1949 Geneva Conventions and could be held accountable by the International Criminal Court for dereliction of duty. In other words, there are no excuses that can be offered for overlooking the use of criminal elements for criminal purposes.

\section{The Responsibility to Protect}

The issue of using imprisoned violent criminals and/or gangsters from the street to assist in a potential or actual genocidal enterprise is unambiguous evidence that a state is clearly unwilling and/or incapable of protecting its citizens. This issue goes directly, of course, to the focus of the concept of "the responsibility to protect." The basic question behind "the responsibility to protect" is "when, if ever, it is appropriate for states to take coercive - and in particular military - action, against another state for the purpose of protecting people at risk in that other state" (International Commission on Intervention and State Sovereignty, 2001, p. 1 of Forward). The concept is, understandably, controversial for it goes against the grain of the "sanctity" of sovereignty going all the way back to the Treaty of Westphalia (1648).

The central theme of "The Responsibility to Protect" is the notion that sovereign states have a responsibility to protect their citizens from "avoidable catastrophe -- from mass murder and rape, from starvation -- but that when they are unwilling or unable to do so, that responsibility must be borne by the broader community of states" (International Commission on Intervention and State Sovereignty, 2001, n.p.). There are two basic principles inherent in the concept of the "responsibility to protect":

A. State sovereignty implies responsibility, and the primary responsibility for the protection of its people lies with the state itself; and 


\section{Journal of African Conflicts and Peace Studies}

B. Where a population is suffering serious harm, as a result of internal war, insurgency, repression or state failure, and the state in question is unwilling or unable to halt or avert it, the principle of non-intervention yields to the international responsibility to protect.

As the authors of the report note: "The foundations of the responsibility to protect, as a guiding principle for the international community of states, lie in, in part, "the obligations inherent in the concept of sovereignty" (International Commission on Intervention and State Sovereignty, 2001, n.p.). In that regard, according to the ICISS (2001), what the concept of "the responsibility to protect" means for the international community" is that it will respond in a timely and effective manner when a nation is guilty of abnegating its responsibilities as a sovereign nation to protect its own people(s) from harm. Thus, it is incumbent upon the international community, and particularly that of the UN Security Council, to uphold its:

A. Responsibility to prevent: to address both the root causes and direct causes of internal conflict and other man-made crises putting populations at risk;

B. Responsibility to react: to respond to situations of compelling human need with appropriate measures, which may include coercive measures like sanctions and international prosecution, and in extreme cases military intervention; and,

C. Responsibility to rebuild: to provide, particularly after a military intervention, full assistance with recovery, reconstruction and reconciliation, addressing the causes of the harm the intervention was designed to halt or

avert" (International Commission on Intervention and State Sovereignty, 2001, n.p.).

Ultimately, then, sovereignty demands that a nation's government and its leaders not only protect the primacy of the nation (the land, government, and so forth) from harm but that it protect its people from harm as well - and not only harm at the hands of outside forces but from the very nation and ruling government themselves. Hypothetically, then, there is no room for despots in the world (e.g., a ruler with absolute power and/or one who wields power oppressively). Concomitantly, the international community has the responsibility to act when a nation and its leaders fail to protect their own citizens. 
Totten: The Release, Transfer and/or Use of Imprisoned Criminals and/or K

\section{Journal of African Conflicts and Peace Studies}

While the concept of "the responsibility to protect" provides a green light of sorts for the international community to intervene when a nation forfeits its legitimate right to sovereignty, complications arise when the international community attempts to act upon the concept. In other words, the concept is an ideal, and how it works in reality is bound to be buffeted by both realpolitik and political will (or the absence of such). It is also bound to be buffeted by how the failing nation reacts to the corrective action, particularly how aggressively and pugnaciously it is in response to the intervention. Still, when all is said and done, the use of criminal elements for potential and/or actual assistance in the commission of crimes against humanity or genocide is a clear signal that the concept and principle of "the responsibility to protect" has been breached, and there is something drastically askew in that nation.

\section{Recommendations}

So, what can genocide scholars, the international community, and society in general learn from such a phenomenon (the use of criminals in the commission of potential crimes against humanity and/or genocide), and what should be done to address it? Listed below are some preliminary thoughts and possibilities:

- First, as noted above, the en masse release of violent criminals prior to the completion of their sentences provides clear evidence that something is awry within a society and should serve as a signal that significant - and probably violent - trouble is brewing within that society. Mass amnesty of criminals, especially those guilty of assault, rape and murder is rare to nonexistent in most, societies unless it is precipitated by some sort of violent conflict that turns a society inside out or upside down such as a civil war, a revolution or a coup d'état. ${ }^{8}$ Upon the release of such prisoners (or sooner, where there is advance warning of such a release), the international community must garner the will to ward off such untoward behavior, demand the immediate capture of such prisoners and apply serious sanctions if the culpable parties fail to heed the demands of the international community.

\footnotetext{
${ }^{8}$ Prisoner of war exchanges between two factions or two countries are much more common but they are a different story; first, they are prisoners whose freedom is desired by a particular society, and second, such exchanges do not involve the freed prisoners remaining in the country in which they were imprisoned thus, at least largely, avoiding a situation where those who are freed will be available to commit crimes within that society.
} 


\section{Journal of African Conflicts and Peace Studies}

- The phenomenon involving the use of violent criminals by a society to carry out its "dirty work" (e.g., harassment, threats, terror, beatings, murder, mass murder) in the commission of potential or actual crimes against humanity or genocide must be integrated into any genocide early warning system and be considered a key genocide early warning signal.

- This phenomenon requires more detailed study via a comparative analysis of various genocides. Subsequent studies might focus on the following: the extent to which convicted -- and particularly violent -- criminals have been released to take part in genocidal processes; the varied activities such individuals took part in vis-à-vis genocide; the way in which the international community either addressed or neglected to address the release of such convicts for the express pursue of taking part in genocide; whether or not the released criminals were held accountable for the crimes they committed during the genocide; and whether or not the leaders and/or military officials who oversaw the release of the convicts and then steered them towards taking part in the genocidal process were held accountable for their misdeeds along this line.

- The release of criminals from jails and prisons for the express purpose of carrying out genocidal actions should be used as just one more piece of evidence to convict those who plan and carry out genocide.

\section{Conclusion}

The use of imprisoned violet criminals (and/or gangsters from the street) is not only egregious, but judicially, socially and, most significantly, morally corrupt, and it sends a signal -- or at least it should -- that something is direly wrong, indeed, abnormal -- in such a society. Indeed, it is clear evidence that the state is failing in some serious way, and is undoubtedly incapable of protecting its own citizens.

Some may question whether such a situation, in fact, constitutes a major genocide early warning signal, but, again, who in a "civil" or "normal" society would not decry, loudly and persistently, criminals being released en masse to take part in criminal ventures? Should that ever happen in a "civil" or "normal" society, the individual or individuals responsible for such would not only have their sanity questioned. Indeed, to even think that such an event would happen in a civil society is so outlandish as to be ludicrous. And that is the point: when such happens in a society, it is a society that is in all likelihood in danger of disintegrating into mass chaos, if not worse. And because of 


\section{Journal of African Conflicts and Peace Studies}

that both situations (the release of hardened criminals from jail and prison for no good apparent reason, and the use of such criminals, including members of the underworld, to do the work of a nation's governmentleaders) should be on the "radar" of any genocide early warning system.

When accused of having perpetrated crimes against humanity and/or genocide, many, if not most, perpetrators automatically deny their responsibility. Such excuses have ranged from claims of having no knowledge of such criminal acts/atrocities to denial of having issued any directives to their underlings to commit such atrocities, and from claims that the actions were the aberrant "work" of a "few" miscreants to assertions that the actions constituted self-defense in the face of attacks against them by their enemies.

When violent criminals -- murders, rapists, and those how have committed such crimes as assault and battery -- are released from prisons and jails in large numbers prior to having served their full sentences and then "allowed" to take part in potential or actual crimes against humanity and/or genocide -- no one can deny the fact that something unmistakably wrong has taken place in that society. Put another way, no one could claim that there was or is any justification for the wholesale release of violent and dangerous criminals from penal institutions into society prior to their having served their mandatory sentences. The same is true of hiring gangsters to carry out the government's work. It simply makes no sense, and no responsible leader would sanction such. Concomitantly, no one could claim ignorance of such an action for its immediate impact would be felt in society in a number of ways. In other words, those perpetrators who release and/or use "common criminals" to assist in the commission of human rights violations and crimes know, without a doubt, that they are engaged in a criminal enterprise. Again, such "agreements" fly in the face of common sense, let alone the dictates of the legal process.

Finally, the use of incarcerated criminals and gangsters from the street by perpetrators of crimes against humanity and genocide is an under-studied phenomenon, and one that deserves more attention. Using criminals to commit illegal acts is an issue that courts must take into consideration when trying alleged perpetrators. Such actions constitute just one more piece of evidence that perpetrators know full well that what they are engaged in is illegal -- be it so-called "ethnic cleansing," crimes against humanity or genocide - and is one more piece of evidence that they are willing to use any means no matter how outlandish to accomplish their aberrant goals. 
Journal of African Conflicts and Peace Studies, Vol. 1, Iss. 2 [2009], Art. 5

\section{Journal of African Conflicts and Peace Studies}

\section{References}

Adalian, Rouben Paul (2004). "The Armenian Genocide," pp. 52-90. In Samuel Totten, William S. Parsons, and Israel W. Charny (Eds.) Century of Genocide: Critical Essays and Eyewitness Testimony. New York: Routledge.

Alvarez, Alex (2001). Governments, Citizens, and Genocide: A Comparative and Interdisciplinary Approach. Bloomington and Indianapolis: Indiana University Press.

Cigar, Norman, and Williams, Paul (2002). Indictment at the Hague: The Milosevic Regime and Crimes of the Balkan Wars. New York: New York University Press.

Cohen, Lenard J. (2001). Serpent in the Bosom: The Rise and Fall of Slobodan Milosevic. Boulder, CO: Westview Press.

Cribb, Robert (2009). "The Indonesian Massacres," pp. 234-262. In Samuel Totten and William S. Parsons (Eds.) Century of Genocide: Critical Essays and Eyewitness Testimony. New York: Routledge.

Cribb, Robert (2004a). "The Indonesian Massacres," pp. 232-260. In Samuel Totten, William S. Parsons, and Israel W. Charny (Eds.) Century of Genocide: Critical Essays and Eyewitness Accounts. New York: Routledge.

Dadrian, Vahakn N. (2001). "The Armenian Genocide: An Interpretation," pp. 52-100. In Jay Winter (Ed.) America and the Armenian Genocide of 1915. New York: Cambridge University Press.

Dadrian, Vahakn N. (1997). The History of the Armenian Genocide: Ethnic Conflict from the Balkans to Anatolia to the Caucasus. Providence, RI: Berghahn Books.

Dadrian, Vahakn N. (2005). "Armenians in Ottoman Turkey and the Armenian Genocide," pp. 67-76. In Dinah L. Shelton (Ed.) Encyclopedia of Genocide and Crimes Against Humanity. New York: Thomson Gale.

Dallaire, Roméo (2005). Shake Hands With the Devil: The Failure of Humanity in Rwanda. New York: Carroll \& Graf Publishers. 
Totten: The Release, Transfer and/or Use of Imprisoned Criminals and/or K

\section{Journal of African Conflicts and Peace Studies}

Des Forges, Alison (1999). Leave None to Tell the Story: Genocide in Rwanda. New York: Human Rights Watch.

Fein, Helen (2000). "The Three P's of Genocide Prevention," pp. 41-66. In Neal Riemer (Ed.) Protection Against Genocide: Mission Impossible? Westport, CT: Praeger Publishers.

Flint, Julie (2004). Sudan: Peace, But At What Price? Testimony Before the U.S. Senate Foreign Relations Comitteee. June 15. Accessed at: http://thinkweb.hrw.org/en/news/2004/06/14/sudan-peace-what-price

Flint, Julie, and De Waal, Alex (2005). Darfur: A Short History of a Long War. London: Zed Books.

Harff, Barbara (1987). "The Etiology of Genocides," pp. 41-59. In Isidor Walliman and Michael N. Dobkowski (Eds.) Genocide and the Modern Age Etiology and Case Studies of Mass Death. Wesport, CT: Greenwood Press.

Hilberg, Raul (1992). Perpetrators, Victims, Bystanders: The Jewish Catastrophe 1933-1945. New York: HarperCollins.

Human Rights Watch (2004). "Sudan: Peace But At What Price?" [Testimony by Julie Flint Before U.S. Senate Foreign Relations Committee.] June 15. New York: Author. Accessed at: http://thinkweb.hrw.org/en/news/2004/06/14/sudan-peace-what-price

Huttenbach, Henry (2004) "Conducting a Comparative Study of Genocide: Rationale and Methodology," pp. 239-247. In Samuel Totten (Ed.) Teaching About Genocide: Issues, Approaches, Resources. Greenwich, CT: Information Age Publishers.

International Commission on Intervention and State Sovereignty (2001). The Responsiblty to Protect: Report of the International Commission on Intervention and State Sovereignty. Ottawa, UN. 


\section{Journal of African Conflicts and Peace Studies}

Littell, Franklin H. (1999). "Early Warning System (EWS)," pp. 261-265. In Israel W. Charny (Ed.) Encyclopedia of Genocide. Volume 1. Santa Barbara, CA: ABC CLIO.

Mazian, Florence (1990). Why Genocide? The Armenian and Jewish Experiences in Perspective. Ames, IA: lowa State University Press.

Naimark, Norman M. (2001). Fires of Hatred: Ethnic Cleansing in Twentieth-Century Europe. Cambridge, MA: Harvard University Press.

Niewyk, Donald (2009). "Holocaust: The Jews," pp. 128-161. In Samuel Totten and William S. Parsons (Eds.) Century of Genocide: Critical Essays and Eyewitness Testimony. New York: Routledge.

Niewyk, Donald, and Nicosia, Francis (2000). The Columbia Guide to the Holocaust. New York: Columbia University Press.

Sell, Louis (2002). Slobodan Milosevic and the Destruction of Yugoslavia. Durham, NC: Duke University Press.

Semelin, Jacques (2003). "Analysis of a Mass Crimes: Ethnic Cleansing in the Former Yugoslavia, 1991-1999," pp. 353-370. In Robert Gellately and Ben Kiernan (Eds.) The Specter of Genocide: Mass Murder in Historical Perspective. New York: Cambridge University Press.

Totten, Samuel (2008). Interview with Survivor of the Rwandan Genocide.

Totten, Samuel, and Bartrop, Paul (2008). Dictionary of Genocide. Volume One. Westport, CT: Greenwood Publishing.

Totten, Samuel, and Parsons, William S. (2009). Century of Genocide: Critical Essays and Eyewitness Accounts. New York: Routledge. 
Totten: The Release, Transfer and/or U se of Imprisoned Criminals and/or K

\section{Journal of African Conflicts and Peace Studies}

Wax, Emily (2004). "In Sudan, A 'Big Sheik' Roams Free." The Washington Post Foreign Service, July 18, p. A01. Accessed at: http://www.washingtonpost.com/wpdyn/articles/A58171-2004Jul17.html

Yahil, Leni (1990). The Holocaust: The Fate of European Jewry. New York: Oxford University Press. 